\title{
Article \\ Glomus mosseae and Pseudomonas fluorescens Application Sustains Yield and Promote Tolerance to Water Stress in Helianthus annuus L.
}

\author{
Meenakshi Sharma ${ }^{1}$, Anil Kumar Delta ${ }^{1}$ and Prashant Kaushik ${ }^{2,3, *}$ \\ 1 Department of Chemistry, Ranchi University, Ranchi 834001, India; meenakshiskkr@gmail.com (M.S.); \\ akumardelta2013@gmail.com (A.K.D.) \\ 2 Kikugawa Research Station, Yokohama Ueki, 2265, Kikugawa 439-0031, Japan \\ 3 Instituto de Conservación y Mejora de la Agrodiversidad Valenciana, Universitat Politècnica de València, \\ 46022 Valencia, Spain \\ * Correspondence: prakau@doctor.upv.es
}

Citation: Sharma, M.; Delta, A.K.; Kaushik, P. Glomus mosseae and Pseudomonas fluorescens Application Sustains Yield and Promote Tolerance to Water Stress in Helianthus annuus L.. Stresses 2021, 1, 305-316. https:// doi.org/10.3390/stresses1040022

Academic Editor: Maria Maddalena Del Gallo

Received: 3 November 2021

Accepted: 15 December 2021

Published: 16 December 2021

Publisher's Note: MDPI stays neutral with regard to jurisdictional claims in published maps and institutional affiliations.

Copyright: (c) 2021 by the authors. Licensee MDPI, Basel, Switzerland. This article is an open access article distributed under the terms and conditions of the Creative Commons Attribution (CC BY) license (https:/ / creativecommons.org/licenses/by/ $4.0 /)$.

\begin{abstract}
The inoculation of sunflower (Helianthus annuus L.) plants with arbuscular mycorrhizal fungi (AMF) and plant growth-promoting rhizobacteria (PGPR) can significantly enhance its growth and yield in a sustainable manner. Drought tolerance is mediated by a combination of direct AMF and PGPR benefits that boost the plant's natural ability to cope with stress, whereas drought mitigation is mediated by indirect AMF and PGPR benefits and increased water uptake. An experiment was carried out to demonstrate the interactive effects of AMF (Glomus mosseae) alone or in association with PGPR (Pseudomonas fluorescens) under water-stressed conditions in order to assess their biofertilizer efficiency. Accordingly, various morphological and biochemical parameters were studied, and the results suggested that all the co-inoculation treatments displayed beneficial effects. Still, the combination of G. mosseae + P. fluorescens showed the maximum increment in all the parameters considered, i.e., plant height and weight, leaves length and width, number of leaves per plant, specific leaf weight, relative leaf water content (RLWC), photosynthetic efficiency, seed length, width, and area, seed yield per plant, number of seeds per flower, days to $50 \%$ flowering, days to maturity, flower and head diameter, harvest index, oil content, fatty acid composition (palmitic acid, oleic acid, stearic acid, and linoleic acid), and total yield. The improvement in different parameters may be attributed to the increased availability of nutrients due to the symbiotic association of AMF and PGPR with plant roots along with enhanced root structures for more water absorption under stressed conditions. Therefore, the results suggested that they offer a promising bio-control strategy for crop protection as biofertilizers combined in one formulation.
\end{abstract}

Keywords: sunflower; mycorrhizal fungi; Pseudomonas; water stress; yield

\section{Introduction}

Sunflower is one of the most valuable sources of edible oils known for its monounsaturated fats. The oil content of about $36-52 \%$ and protein content of $28-32 \%$ are found in sunflower seeds [1]. It also contains vitamins A, D, E, and K, which renders them beneficial in averting heart diseases [2,3]. Therefore, to enhance the productivity of this important oilseed crop, various biotic or abiotic factors that could affect its growth and development should be considered carefully. Drought (or water deficit) stress is one of these limiting abiotic factors that has received a lot of attention because it is the most likely constraint for agricultural productivity [4]. Drought happens when the plant's water requirements are not fully met, and this occurs when the amount of transpired water exceeds the amount of water taken up by the roots, which is caused by insufficient precipitation, low groundwater levels, or water retention by soil particles $[5,6]$. Water scarcity causes stomatal closure, which reduces $\mathrm{CO}_{2}$ influx, lowering photosynthetic activity and carbon partitioning [7], 
as well as plant productivity and agricultural produce. Further, increasing environmental problems triggered by chemical fertilizers have created the need to use biofertilizers for sustainable crop production [4]. In this context, plant growth-promoting rhizobacteria (PGPR) and arbuscular mycorrhizal fungi (AMF) represent the two most important groups of beneficial rhizospheric micro-organisms which may act as biofertilizers [5]. The microorganisms capable of colonizing the rhizosphere may be categorized based on their way of interaction with plants, and particularly with roots, some act as pathogens while others produce beneficial effects [6,7].

The beneficial effects of PGPR and AMF on sunflower plants have been well-documented through many studies. Mycorrhizal fungi, such as Glomus mosseae, help in increasing water and mineral uptake by roots, subsequently improving the soil structure $[8,9]$. The other significant benefit of AMF includes protecting the host plant from pathogenic infections caused by various soil microbes such as bacteria, fungi, and nematodes $[10,11]$. This is because mycorrhizal fungi encourage various defense mechanisms, including competition for photosynthates with pathogenic microbes and the expression of disease-resistance genes $[12,13]$. They also stimulate the expression of antioxidant enzymes and reduce malondialdehyde (MDA) production, an indicator of plant-membrane damage by lipid peroxidation [3]. Arbuscular mycorrhizal fungi influence the functioning of the root system, affect plant growth at different levels, and help reduce fertilizer input in the agricultural system without any significant yield loss [14,15]. Moreover, numerous studies have suggested that the AMF application in sunflower augmented its growth parameters and seed yield, even under biotic and abiotic stress conditions, via complex interactions with the host plant $[16,17]$.

Plant growth-promoting rhizobacteria influence plant growth either directly by stimulating plant metabolism or by generating phytohormones such as auxins and gibberellins, solubilizing minerals, fixing atmospheric-nitrogen, or indirectly by mitigating detrimental effects of phytopathogenic microbes and improving stress tolerance. They also affect plant growth by increasing the availability of nutrients and reducing incidences of pathogenic infestation $[18,19]$. Further, inoculation with $P$. fluorescens may also accelerate seed germination, improve the emergence of seedlings, respond to various external stress factors, and enhance root structures [20,21]. Due to these properties, various inoculants of PGPR that tend to promote plant growth via one of the mechanisms (i.e., suppression of diseases in plants, improved absorption of nutrients, or production of phytohormones) are being commercialized. One such bacterial species is Pseudomonas which can be efficiently used as a bio-control agent for plants. The present study, therefore, aims to investigate the beneficial effects of AMF (G. mosseae) inoculation alone and in combination with PGPR (P. fluorescens) on the biochemical and morphological characteristics of sunflower and their possible use as biofertilizers.

\section{Results}

Significant variations were observed among all the treatments $(<0.01)$ for all the characteristics analysed in the present study, except for harvest index and specific leaf weight (Table 1). The effects of G. mosseae and P. fluorescens inoculation on different morphological and biochemical characteristics of sunflower were investigated and recorded in Tables 2 and 3. Although all the treatments produced significant results, T6 was found to be the most efficient in enhancing the quality, as well as quantity, of the yield. 
Table 1. Variance analysis of the effects of different treatments on the morphological and biochemical traits of sunflower.

\begin{tabular}{|c|c|c|}
\hline Traits & Treatments & Residuals \\
\hline df & 5 & 10 \\
\hline Leaf length (cm) & 172.947 & 1.814 \\
\hline $\mathrm{F}$ & 95.35 & \\
\hline$p$ & $<0.001$ & \\
\hline Leaf width (cm) & 229.967 & 1.833 \\
\hline $\mathrm{F}$ & 125.44 & \\
\hline$p$ & $<0.001$ & \\
\hline Total yield (kg) & 1.309 & 0.002 \\
\hline $\mathrm{F}$ & 561.93 & \\
\hline$p$ & $<0.001$ & \\
\hline Plant height $(\mathrm{cm})$ & 1764.668 & 24.361 \\
\hline $\mathrm{F}$ & 72.44 & \\
\hline$p$ & $<0.001$ & \\
\hline Plant weight (kg) & 1.755 & 0.090 \\
\hline $\mathrm{F}$ & 19.51 & \\
\hline$p$ & $<0.001$ & \\
\hline Flower diameter $(\mathrm{cm})$ & 77.714 & 0.189 \\
\hline $\mathrm{F}$ & 411.43 & \\
\hline$p$ & $<0.001$ & \\
\hline Seed area $\left(\mathrm{mm}^{2}\right)$ & 6224.013 & 109.649 \\
\hline $\mathrm{F}$ & 56.76 & \\
\hline$p$ & $<0.001$ & \\
\hline Seed length (mm) & 97.014 & 7.087 \\
\hline $\mathrm{F}$ & 13.69 & \\
\hline$p$ & $<0.001$ & \\
\hline Seed width (mm) & 16.426 & 0.520 \\
\hline $\mathrm{F}$ & 31.59 & \\
\hline$p$ & $<0.001$ & \\
\hline Seed per flower & $199,304.722$ & 2884.389 \\
\hline $\mathrm{F}$ & 69.10 & \\
\hline$p$ & $<0.001$ & \\
\hline$\times 1000 \mathrm{SW}(\mathrm{g})$ & 7560.699 & 92.534 \\
\hline $\mathrm{F}$ & 81.71 & \\
\hline$p$ & $<0.001$ & \\
\hline Days to $50 \%$ flowering & 9.600 & 0.333 \\
\hline $\mathrm{F}$ & 28.80 & \\
\hline$p$ & $<0.001$ & \\
\hline Days to maturity & 12.400 & 0.133 \\
\hline $\mathrm{F}$ & 93.00 & \\
\hline$p$ & $<0.001$ & \\
\hline Head diameter $(\mathrm{cm})$ & 49.932 & 0.324 \\
\hline $\mathrm{F}$ & 154.27 & \\
\hline$p$ & $<0.001$ & \\
\hline No. of leaves per plant & 40.161 & 0.439 \\
\hline $\mathrm{F}^{1}$ & 91.41 & \\
\hline$p$ & $<0.001$ & \\
\hline Specific leaf weight (g) & 0.571 & 0.064 \\
\hline $\mathrm{F}$ & 8.98 & \\
\hline$p$ & 0.015 & \\
\hline
\end{tabular}


Table 1. Cont.

\begin{tabular}{|c|c|c|}
\hline Traits & Treatments & Residuals \\
\hline Relative leaf water content & 175.977 & 8.314 \\
\hline $\mathrm{F}$ & 21.17 & \\
\hline$p$ & 0.002 & \\
\hline $\begin{array}{l}\text { Photosynthetic efficiency } \\
\text { (SPAD reading) }\end{array}$ & 18.506 & 0.296 \\
\hline $\mathrm{F}$ & 62.55 & \\
\hline$p$ & $<0.001$ & \\
\hline Seed yield per plant (g) & 246.235 & 1.828 \\
\hline $\mathrm{F}$ & 134.72 & \\
\hline$p$ & $<0.001$ & \\
\hline Harvest Index & 80.374 & 13.926 \\
\hline $\mathrm{F}$ & 5.77 & \\
\hline$p$ & 0.039 & \\
\hline Oil content & 12.113 & 0.181 \\
\hline $\mathrm{F}$ & 67.09 & \\
\hline$p$ & $<0.001$ & \\
\hline Palmitic acid & 6.290 & 0.107 \\
\hline $\mathrm{F}$ & 58.68 & \\
\hline$p$ & $<0.001$ & \\
\hline Stearic acid & 2.816 & 0.201 \\
\hline $\mathrm{F}$ & 14.03 & \\
\hline$p$ & 0.006 & \\
\hline Oleic acid & 118.098 & 0.651 \\
\hline $\mathrm{F}$ & 181.32 & \\
\hline$p$ & $<0.001$ & \\
\hline Linoleic acid & 93.447 & 0.182 \\
\hline $\mathrm{F}$ & 514.49 & \\
\hline$p$ & $<0.001$ & \\
\hline Root colonization (\%) & 6558.210 & 2.351 \\
\hline $\mathrm{F}$ & 1681.44 & \\
\hline$p$ & $<0.001$ & \\
\hline
\end{tabular}

Table 2. Effects of different treatments on various morphological characteristics of sunflower.

\begin{tabular}{ccccccc}
\hline Traits & T1 & T2 & T3 & T4 & T5 & T6 \\
\hline Leaf length $(\mathrm{cm})$ & $19.67 \pm 1.15 \mathrm{~d}$ & $22.67 \pm 2.31 \mathrm{~d}$ & $26.67 \pm 0.58 \mathrm{c}$ & $29.33 \pm 0.58 \mathrm{bc}$ & $32.50 \pm 0.50 \mathrm{~b}$ & $41.00 \pm 1.73 \mathrm{a}$ \\
\hline Leaf width $(\mathrm{cm})$ & $15.67 \pm 3.06 \mathrm{~d}$ & $21.00 \pm 3.00 \mathrm{c}$ & $26.33 \pm 0.58 \mathrm{~b}$ & $29.33 \pm 1.53 \mathrm{~b}$ & $36.00 \pm 1.00 \mathrm{a}$ & $38.67 \pm 2.89 \mathrm{a}$ \\
\hline Total yield $(\mathrm{kg})$ & $0.40 \pm 0.02 \mathrm{f}$ & $0.67 \pm 0.09 \mathrm{e}$ & $0.86 \pm 0.09 \mathrm{~d}$ & $1.37 \pm 0.13 \mathrm{c}$ & $1.63 \pm 0.10 \mathrm{~b}$ & $2.17 \pm 0.14 \mathrm{a}$ \\
\hline Plant height $(\mathrm{cm})$ & $71.79 \pm 3.77 \mathrm{c}$ & $80.56 \pm 7.40 \mathrm{c}$ & $90.71 \pm 0.41 \mathrm{c}$ & $119.17 \pm 0.76 \mathrm{~b}$ & $123.90 \pm 4.45 \mathrm{~b}$ & $149.21 \pm 13.68 \mathrm{a}$ \\
\hline Plant weight $(\mathrm{kg})$ & $0.25 \pm 0.16 \mathrm{c}$ & $0.46 \pm 0.00 \mathrm{c}$ & $0.52 \pm 0.01 \mathrm{c}$ & $0.88 \pm 0.28 \mathrm{bc}$ & $1.46 \pm 0.37 \mathrm{ab}$ & $2.27 \pm 0.74 \mathrm{a}$ \\
\hline Flower diameter $(\mathrm{cm})$ & $11.83 \pm 0.29 \mathrm{f}$ & $14.50 \pm 1.00 \mathrm{e}$ & $16.33 \pm 0.58 \mathrm{~d}$ & $20.33 \pm 0.58 \mathrm{c}$ & $22.83 \pm 1.26 \mathrm{~b}$ & $25.00 \pm 1.00 \mathrm{a}$ \\
\hline Seed area $\left(\mathrm{mm}^{2}\right)$ & $93.90 \pm 14.31 \mathrm{~d}$ & $148.23 \pm 21.33 \mathrm{c}$ & $176.03 \pm 0.87 \mathrm{bc}$ & $179.90 \pm 0.96 \mathrm{~b}$ & $194.93 \pm 12.15 \mathrm{~b}$ & $227.90 \pm 24.34 \mathrm{a}$ \\
\hline Seed length $(\mathrm{mm})$ & $10.87 \pm 6.97 \mathrm{~b}$ & $21.10 \pm 0.66 \mathrm{a}$ & $23.00 \pm 0.44 \mathrm{a}$ & $24.20 \pm 0.53 \mathrm{a}$ & $25.03 \pm 0.29 \mathrm{a}$ & $26.70 \pm 1.21 \mathrm{a}$ \\
\hline Seed width $(\mathrm{mm})$ & $8.13 \pm 0.81 \mathrm{c}$ & $9.57 \pm 0.23 \mathrm{bc}$ & $10.00 \pm 0.20 \mathrm{bc}$ & $10.53 \pm 0.32 \mathrm{~b}$ & $11.17 \pm 0.21 \mathrm{~b}$ & $15.03 \pm 1.94 \mathrm{a}$ \\
\hline Seed per flower & $488.33 \pm 33.29 \mathrm{e}$ & $709.00 \pm 98.91 \mathrm{~d}$ & $821.33 \pm 43.09 \mathrm{~cd}$ & $903.33 \pm 22.48 \mathrm{bc}$ & $1002.00 \pm 48.14 \mathrm{~b}$ & $1244.33 \pm 148.04 \mathrm{a}$ \\
\hline X1000SW $(\mathrm{g})$ & $99.53 \pm 24.20 \mathrm{e}$ & $138.92 \pm 12.76 \mathrm{~d}$ & $165.54 \pm 10.21 \mathrm{~cd}$ & $181.06 \pm 2.13 \mathrm{bc}$ & $198.03 \pm 8.22 \mathrm{~b}$ & $245.86 \pm 20.45 \mathrm{a}$ \\
\hline Days to $50 \%$ flowering & $75.00 \pm 0.00 \mathrm{a}$ & $72.00 \pm 1.41 \mathrm{~b}$ & $70.00 \pm 0.00 \mathrm{bc}$ & $70.00 \pm 0.00 \mathrm{bc}$ & $70.00 \pm 0.00 \mathrm{bc}$ & $69.00 \pm 0.00 \mathrm{c}$ \\
\hline Days to maturity & $102.50 \pm 0.71 \mathrm{a}$ & $102.00 \pm 0.00 \mathrm{a}$ & $100.00 \pm 0.00 \mathrm{~b}$ & $99.00 \pm 0.00 \mathrm{~b}$ & $97.00 \pm 0.00 \mathrm{c}$ & $96.50 \pm 0.71 \mathrm{c}$ \\
\hline Head diameter $(\mathrm{cm})$ & $10.29 \pm 1.71 \mathrm{~d}$ & $11.84 \pm 0.06 \mathrm{~cd}$ & $13.58 \pm 0.35 \mathrm{c}$ & $17.34 \pm 0.72 \mathrm{~b}$ & $20.84 \pm 1.00 \mathrm{a}$ & $22.62 \pm 0.86 \mathrm{a}$ \\
\hline No. of leaves per plant & $16.89 \pm 1.21 \mathrm{e}$ & $19.64 \pm 0.09 \mathrm{de}$ & $21.02 \pm 0.38 \mathrm{~cd}$ & $23.79 \pm 0.76 \mathrm{bc}$ & $26.10 \pm 0.39 \mathrm{~b}$ & $29.16 \pm 1.89 \mathrm{a}$ \\
\hline
\end{tabular}


Table 2. Cont.

\begin{tabular}{|c|c|c|c|c|c|c|}
\hline Traits & T1 & $\mathrm{T} 2$ & T3 & $\mathrm{T} 4$ & T5 & T6 \\
\hline $\begin{array}{l}\text { Specific leaf weight } \\
(\mathrm{g})\end{array}$ & $0.75 \pm 0.17 \mathrm{~b}$ & $1.06 \pm 0.01 b$ & $1.14 \pm 0.02 b$ & $1.33 \pm 0.04 \mathrm{ab}$ & $1.59 \pm 0.13 \mathrm{ab}$ & $2.29 \pm 0.67 \mathrm{a}$ \\
\hline $\begin{array}{l}\text { Relative leaf water } \\
\text { content }\end{array}$ & $55.78 \pm 4.04 c$ & $61.73 \pm 2.00 \mathrm{bc}$ & $64.44 \pm 0.40 \mathrm{bc}$ & $68.25 \pm 1.18 b$ & $72.15 \pm 0.55 \mathrm{ab}$ & $82.92 \pm 7.91 a$ \\
\hline $\begin{array}{l}\text { Photosynthetic } \\
\text { efficiency (SPAD } \\
\text { reading) }\end{array}$ & $32.22 \pm 1.05 \mathrm{~d}$ & $34.47 \pm 1.69 \mathrm{~cd}$ & $36.37 \pm 0.28 b c$ & $37.95 \pm 0.64 a b$ & $39.52 \pm 0.34 a$ & $40.11 \pm 0.42 a$ \\
\hline $\begin{array}{l}\text { Seed yield per plant } \\
(\mathrm{g})\end{array}$ & $15.33 \pm 1.41 \mathrm{e}$ & $17.55 \pm 1.04 \mathrm{de}$ & $22.66 \pm 2.81 \mathrm{~cd}$ & $28.27 \pm 0.21 c$ & $36.15 \pm 0.33 b$ & $43.92 \pm 3.54 a$ \\
\hline Harvest Index & $4.20 \pm 0.17 \mathrm{~b}$ & $5.62 \pm 0.43 b$ & $8.34 \pm 1.25 \mathrm{ab}$ & $10.93 \pm 0.88 \mathrm{ab}$ & $13.57 \pm 0.02 \mathrm{ab}$ & $21.61 \pm 9.62 \mathrm{a}$ \\
\hline
\end{tabular}

Means \pm SD followed by the same letters are not significantly different at $p<0.05$ (Newman-Keuls test).

Table 3. Effects of different treatments on various biochemical characteristics and root colonization (\%) of sunflower.

\begin{tabular}{ccccccc}
\hline Traits & T1 & T2 & T3 & T4 & T5 & T6 \\
\hline Oil content & $26.59 \pm 0.62 \mathrm{c}$ & $27.77 \pm 0.15 \mathrm{c}$ & $28.23 \pm 0.22 \mathrm{c}$ & $30.14 \pm 0.11 \mathrm{~b}$ & $31.80 \pm 1.22 \mathrm{ab}$ & $32.90 \pm 0.28 \mathrm{a}$ \\
\hline Palmitic acid & $3.79 \pm 0.08 \mathrm{e}$ & $5.08 \pm 0.83 \mathrm{de}$ & $5.99 \pm 0.23 \mathrm{~cd}$ & $6.69 \pm 0.04 \mathrm{bc}$ & $7.97 \pm 0.02 \mathrm{ab}$ & $8.51 \pm 0.53 \mathrm{a}$ \\
\hline Stearic acid & $2.57 \pm 1.02 \mathrm{c}$ & $3.33 \pm 0.06 \mathrm{bc}$ & $3.66 \pm 0.13 \mathrm{bc}$ & $4.43 \pm 0.04 \mathrm{abc}$ & $4.97 \pm 0.06 \mathrm{ab}$ & $5.85 \pm 0.85 \mathrm{a}$ \\
\hline Oleic acid & $40.06 \pm 0.18 \mathrm{~d}$ & $41.69 \pm 0.76 \mathrm{~d}$ & $49.23 \pm 2.43 \mathrm{c}$ & $52.82 \pm 1.20 \mathrm{~b}$ & $56.62 \pm 0.55 \mathrm{a}$ & $58.67 \pm 0.47 \mathrm{a}$ \\
\hline Linoleic acid & $31.82 \pm 1.16 \mathrm{e}$ & $33.98 \pm 0.02 \mathrm{~d}$ & $37.72 \pm 0.03 \mathrm{c}$ & $39.05 \pm 0.32 \mathrm{c}$ & $46.77 \pm 0.18 \mathrm{~b}$ & $48.89 \pm 0.45 \mathrm{a}$ \\
\hline Root colonization $(\%)$ & $0.00 \pm 0.00 \mathrm{e}$ & $38.92 \pm 4.18 \mathrm{~d}$ & $56.77 \pm 1.90 \mathrm{~b}$ & $0.00 \pm 0.00 \mathrm{e}$ & $43.40 \pm 5.91 \mathrm{c}$ & $68.45 \pm 3.18 \mathrm{a}$ \\
\hline
\end{tabular}

Means \pm SD followed by the same letters are not significantly different at $p<0.05$ (Newman-Keuls test).

\subsection{Morphological Characteristics}

Leaf length increased by $15 \%$ with T2, 35\% with T3, $49 \%$ with T4, $65 \%$ with T5, and $108 \%$ with T6 as compared with T1; leaf width increased by $34 \%$ with $\mathrm{T} 2,68 \%$ with $\mathrm{T} 3,87 \%$ with T4, $130 \%$ with T5, and $147 \%$ with T6. The combined efficiency of AMF and PGPR for plant growth and development can further be confirmed with the increase in the number of leaves per plant, the maximum with T6 (73\%) and minimum with T2 (16\%), while $\mathrm{T} 3, \mathrm{~T} 4$, and $\mathrm{T} 5$ produced a corresponding increase of $24 \%, 41 \%$, and $55 \%$, respectively. The leaves of the sunflower plant increased not only in number but also in terms of weight after inoculation, i.e., the specific leaf weight increased by $41 \%, 52 \%, 77 \%, 112 \%$, and $205 \%$ with T2, T3, T4, T5, and T6, respectively. Inoculation with G. mosseae + P. fluorescens showed notable effects on plant height as well, where it produced progress of $12 \%$ with T2, 26\% with T3, 66\% with T4, 73\% with T5, and 108\% with T6. However, the most significant variations were recorded in plant weight where T6 produced a dramatic increase of about $808 \%$, while T2, T3, T4, and T5 also produced remarkable increments of $84 \%, 108 \%, 252 \%$, and $484 \%$, respectively, as compared to T1. In addition, T6 also significantly enhanced flower characteristics with an increase of $111 \%$ in flower diameter, followed by $93 \%$ with $\mathrm{T} 5$, $72 \%$ with $\mathrm{T} 4,38 \%$ with $\mathrm{T} 3$, and $22 \%$ with $\mathrm{T} 2$. The head diameter also reported remarkable growths of $15 \%$ with T2, $32 \%$ with T3, $69 \%$ with T4, $103 \%$ with T5, and $120 \%$ with T6.

As far as the characteristics of seeds were concerned, the dual combination of $G$. mosseae and P. fluorescens was found to be the most effective rather than their separate applications. The seed area increased by $58 \%, 87 \%, 91 \%, 107 \%$, and $143 \%$ respectively; seed length by $94 \%, 111 \%, 123 \%, 130 \%$, and $146 \%$ respectively; and seed width by $18 \%, 23 \%$, $29 \%, 37 \%$, and $85 \%$ respectively after treatment with $\mathrm{T} 2, \mathrm{~T} 3, \mathrm{~T} 4, \mathrm{~T} 5$, and T6. The number of seeds per flower exhibited a maximum increase with T6 (155\%), followed by T5 (105\%), T4 $(85 \%)$, T3 $(68 \%)$, and T2 (45\%). In the case of seed yield, there were dramatic increments of $136 \%$ and $186 \%$ after treatment with $\mathrm{T} 5$ and T6; however, treatments $\mathrm{T} 3$ and $\mathrm{T} 4$ were also significant with an increase of $48 \%$ and $84 \%$, respectively. Further, the increase of $39 \%, 66 \%$, 
$82 \%, 99 \%$, and $147 \%$ was observed in $\times 1000$ seed weight when subjected to treatments $\mathrm{T} 2$, T3, T4, T5, and T6, respectively. In addition to the upgraded structural features of different plant parts, the inoculation of G. mosseae and P. fluorescens also showed an improvement in total yield, which increased by $67 \%$ after treatment with T2, 115\% with T3, 242\% with T4, $307 \%$ with T5, and a maximum increase of $442 \%$ with T6. It is, however, worth mentioning here that the effects of $G$. mosseae and P. fluorescens inoculations on the number of days to $50 \%$ flowering did not show any significant variations, and exhibited only a nominal decrease of $4 \%$ with T2, 7\% with T3, T4, T5 each, and 8\% with T6. Similarly, the number of days to maturity remained almost the same with T2, decreased by $2 \%$ with T3, 3\% with T4, $5 \%$ with T5, and 6\% with T6. Furthermore, the harvest index also increased by 34\%, 98\%, $160 \%, 223 \%$, and $415 \%$ after treatment of the plants with T2, T3, T4, T5, and T6, respectively. Furthermore, relative leaf water content was also found to be enhanced by $11 \%, 16 \%, 22 \%$, $29 \%$, and 49\% with T2, T3, T4, T5, and T6, respectively. Regarding photosynthetic efficiency, it was observed that T2 (7\%) and T3 (13\%) showed minor differences. However, treatments T5 and T6 were quite efficient, displaying $23 \%$ and $24 \%$ increments, respectively.

\subsection{Biochemical Characteristics}

The oil content exhibited only a marginal increase of $4 \%, 6 \%, 13 \%, 20 \%$, and $24 \%$ with T2, T3, T4, T5, and T6, respectively, which revealed that only a combined G. mosseae and $P$. fluorescens formulation could produce a notable increase in the sunflower oil content. Nevertheless, the symbiotic associations of AMF and PGPR with sunflower plants were also found to be favorable for its acid content, as palmitic acid increased by $34 \%, 58 \%, 77 \%$, $110 \%$, and $125 \%$; stearic acid increased by $30 \%, 42 \%, 72 \%, 93 \%$, and $128 \%$; oleic acid by $4 \%, 23 \%, 32 \%, 41 \%$, and $46 \%$; and linoleic acid increased by $7 \%, 19 \%, 23 \%, 47 \%$, and $54 \%$ after following the treatments T2, T3, T4, T5, and T6, respectively. No root colonization (\%) was determined for the T1 and T4, respectively. At the same time, T2 (39.92\%) and T3 $(56.77 \%)$ showed less root colonization (\%) under stress conditions as compared to the normal conditions T5 (43.40\%) and T6 (68.45\%), respectively.

\section{Discussion}

Results of the study as recorded in Table 2 revealed that AMF (G. mosseae) and PGPR (P. fluorescens) inoculation presented significant increments in all the growth parameters of sunflower plants. This may be attributed to the fact that these bioinoculants led to an increase in the surface area of roots, subsequently enhancing their water and mineral absorption efficiency, particularly slow dissolving mineral ions such as phosphorus, and resulting in better plant growth under water stress [22,23]. The reason might be the organic acids produced by plant growth-promoting micro-organisms, chelating the phosphatebound cations, and increasing phosphorus accessibility in the soil [24,25]. The mycorrhiza hyphae extension can penetrate the soil pores which are inaccessible to root hairs subsequently absorbing more water than non-mycorrhizal plants. The improvements in plant growth parameters after AMF and PGPR inoculation were further supported by earlier experiments on sesame [26] and mustard [27,28].

In general, AMF inoculated sunflower plants possess larger leaves than non-inoculated plants as shown in Table 2. The photosynthetic rate associated with the chlorophyll content may be responsible for augmented leaf characteristics (leaf length and width), an increase in the number of leaves, and specific leaf weight [16,29]. Enhanced rate of water uptake, aided by AMF such as G. mosseae through upgraded hydraulic conductivity helps in increasing photosynthetic efficiency and consequently leaf area and leaf conductance [30,31]. These observations confirm the findings of other researchers, which showed an increased number of leaves per plant after AMF and PGPR inoculation in sunflower [32,33]. We observed the positive effects of G. mosseae and P. fluorescens inoculation on seed characteristics as shown in Table 2, which were also in agreement with the analysis of Arif et al. [34] which revealed that the inoculated sunflower plants had a significantly higher number of seeds per flower in addition to improved structural features, i.e., length, width, and area of 
seed [34]. AMF also interacts with Rhizobacteria, which promotes plant growth. As PSB solubilizes sparingly accessible phosphorous compounds into orthophosphate, which AMF may absorb and transport to the host plant, AMF and phosphate solubilizing bacteria (PSB) could interact synergistically and improve plant health and productivity. Further, the study also indicated a significant increase in the yield of sunflower seeds. This may be explained by the fact that mycorrhizae symbiosis develops the photosynthetic source for plants through increased leaf area so that the crops might lead to a greater yield of seeds [35,36].

Furthermore, we also observed the augmented flower characteristics (flower diameter and head diameter) of sunflower after application of G. mosseae and P. fluorescens. However, the G. mosseae and P. fluorescens inoculations did not produce many variations in the number of days to $50 \%$ flowering and number of days to maturity (Table 2). The large size of flowers in AMF treated sunflower plants (which was again due to enhanced photosynthetic rate and increased photosynthate accumulation) subsequently leads to an increase in plant weight, $[29,37]$ also observed in this investigation. The findings of other researchers also suggested a larger head diameter in AMF inoculated sunflower plants than in non-inoculated plants [33,38]. The increase in flower head diameter and the corresponding increase in plant weight, along with the increase in plant height can be ascribed to the improved uptake of some nutrients such as boron through root colonization with AMF. It should be noted that sunflower is considered sensitive to a lower boron supply, and deficiency may hinder its vegetative growth [39]. According to different studies, plant height, inter-nodal length, and flower head diameter increased significantly in sunflower plants with sufficient boron nutrition as compared to the control [40,41]. However, further investigations are required to confirm the significance of boron nutrition in other plant growth parameters. The increase in total yield, as per our observations, might also have resulted from improved root structure in inoculated sunflower plants leading to more water and nutrient absorption. The increase in the total yield of sunflower observed after AMF and PGPR application has been supported by numerous other studies on various crops such as switchgrass (Panicum virgatum) [42] and maize (Zea mays) [43,44].

Arbuscular mycorrhizal fungi pre-treated sunflower plants displayed more water absorption over other solutions of sugar, salt, kinetin, and salicylic acid [45]. Mechanisms significant for drought resistance in plants include reduced loss of water via transpiration, maintenance of membrane stability, and regulated osmotic adjustment. Application of G. mosseae enhances the root hydraulic conductivity at a low water potential of soil, which eventually influences the rate of transpiration, the resistance of leaves, and crop yield [46]. The increase in RLWC after G. mosseae inoculation also suggested more osmotic adjustment in the roots of inoculated plants at a low-water potential. Arbuscular mycorrhizal fungi are known to stimulate plant growth and produce plant hormones such as auxin, cytokinin, and gibberellin $[47,48]$. Furthermore, PGPR can significantly affect plant growth through increased nitrogen uptake, phytohormones synthesis, and mineral dissolution [49]. Inoculation with both AMF and PGPR thereby increased spore abundance, root colonization rate, and phosphorus content in tissues of sunflower at later stages of experiment $[47,50,51]$. Nevertheless, AMF species differ in the extent of benefits conferred by them on the development of host plants [36].

The higher colonization rates of G. mosseae, irrespective of water content in the soil, suggested greater adaptability of this species to native soils even under drought conditions. [52]. The present study also reported an increase in oil content under the influence of both G. mosseae and P. fluorescens. Any factor which is known to augment the biomass will improve the grain yield and eventually the oil yield owing to a higher rate of photosynthesis and increased photosynthates generation [53]. Majeed et al. [54] reported a substantial increase in the oil content of sunflower with the help of PGPR-based fertilizers [54]. Moreover, the fatty acid composition (palmitic acid, stearic acid, oleic acid, linoleic acid) of seed oil was also found to be enhanced significantly, as shown in Table 3. Owing to the beneficial effects of these bioinoculants on sunflower plants, it may be concluded that 
G. mosseae and P. fluorescens provide a promising strategy to upgrade their structural and biochemical characteristics with low chemical input and result in a better crop yield.

\section{Materials and Methods}

\subsection{Planting Material and Experimental Details}

The experiment used a randomized complete block design with five replicates of each treatment to compare the findings using the popular hybrid PSH-996 (Punjab Agricultural University, Ludhiana, India). Polyhouse used in this study was settled in, Jharkhand, India $\left(24^{\circ} 22^{\prime} 18^{\prime \prime} \mathrm{N}, 86^{\circ} 19^{\prime} 27^{\prime \prime} \mathrm{E}\right)$. There were 10 pots of every treatment. The soil was obtained from the experimental site and mixed in a 3:1 ratio with sand (soil:sand). Further, this mixture was sieved through a $2 \mathrm{~mm}$ sieve and autoclaved for two days at $121^{\circ} \mathrm{C}$ for two $\mathrm{h}$. Sunflower seeds were surface sterilized and grown in earthen pots in a polyhouse setting. Each pot was administered $10 \%$ of G. mosseae inoculum, either alone or in combination with $P$. fluorescens. The effect of these bio inoculants on various growth parameters of sunflower was determined under limited water conditions. The performance under reduced irrigations was determined by withholding irrigation during anthesis and soft dough crop growth stages [55]. Under normal conditions, six irrigations were applied during the crop season as suggested by Punjab Agricultural University, Ludhiana for a successful sunflower production under Northern Indian plains. Whereas in the treatments screened for water stress, only two irrigation schedules were performed during the crop season to generate a water stress environment as described in our previous work [55]. Hoagland's nutrient solution without $P(100 \mathrm{~mL} /$ pot $)$ was applied after every 15 th day of transplantation [56]. A package of practices was followed for various agronomical practices as defined elsewhere [57].

\subsection{Inoculation of AM Fungi and Pseudomonas fluorescens}

Six treatments were evaluated in the experiment, i.e., $\mathrm{T}_{1}$ : control (drought-stressed plants), $\mathrm{T}_{2}$ : G. mosseae inoculation under drought stress, $\mathrm{T}_{3}:$ G. mosseae + P. fluorescens inoculation under drought stress, $\mathrm{T}_{4}$ : normal irrigation, $\mathrm{T}_{5}: G$. mosseae inoculation under normal watering, $\mathrm{T}_{6}$ : G. mosseae + P. fluorescens inoculation under normal watering. For single AMF treatment, $100 \mathrm{~g}$ of G. mosseae was supplemented per pot. For P. fluorescens treatment, all the seeds were dipped in the nutrient broth medium for $10 \mathrm{~min}$. In consortium treatment, both were applied. Overall, the experiment had six treatments, as follows:

Control: T1

G. mosseae: $\mathrm{T} 2$

G. mosseae + P. fluorescens: T3

Normal: T4

G. mosseae: $\mathrm{T} 5$

G. mosseae + P. fluorescens: T6

\subsection{Plant Harvest and Analysis}

Plants were harvested after 120 days of inoculation (DOI), and the effect of bioinoculants on various growth parameters was reported.

\subsubsection{Morphological Characteristics}

Plant height $(\mathrm{cm})$ was recorded after 120 DOI by a $1 \mathrm{~m}$ scale from ground level to the head attachment of the plant (after attaining physiological maturity), and plant weight $(\mathrm{kg})$ was measured using the weighing balance. Leaf length $(\mathrm{cm})$ and leaf width $(\mathrm{cm})$ were determined using a centimetre scale, and the number of leaves (per plant) was calculated as the average number of leaves at the stage of maturity. Specific leaf weight (g) (SLW) was measured as the total weight of the leaves divided by the number of plant leaves. The head diameter $(\mathrm{cm})$ and flower diameter $(\mathrm{cm})$ were recorded as the distance between two ends of the head and flower, respectively, at the time of maturity. The seed length $(\mathrm{mm})$, seed width $(\mathrm{mm})$, and seed area $\left(\mathrm{mm}^{2}\right)$ were measured after harvesting the crop, and the 
seed yield per plant (g) was determined as the average weight of the harvested seeds. The number of seeds per flower was determined by calculating the average value of the total number of seeds. Days to $50 \%$ flowering were counted from the sowing date until the opening of approximately $50 \%$ of the flower buds into flowers. Similarly, days to maturity were recorded from the sowing date until complete maturity (when the heads' backside turned brown). The harvest index (HI) was predicted at maturity using the formula $\mathrm{HI}=100 \times$ seed yield $/$ total biomass (seed yield + vegetative mass).

\subsubsection{Biochemical Characteristics and Root Colonization (\%)}

The relative leaf water content (RLWC) was estimated using $100 \mathrm{mg}$ fresh weight of leaf discs, kept in distilled water till saturation. The leaf discs were taken out after $6 \mathrm{~h}$, then water was blotted off from the surface of the discs without any pressure. The leaf discs were then weighed carefully to obtain a saturated weight. Finally, the dry weight was estimated after drying the leaf discs for $72 \mathrm{~h}$ at $70{ }^{\circ} \mathrm{C}$. RLWC was then calculated using the formula, RLWC $=100 \times(($ fresh weight - dry weight $) /($ saturated weight - dry weight $))$. The photosynthetic efficiency of leaves was measured using a soil plant analysis development (SPAD) meter as SPAD reading (SPAD 502 Plus Chlorophyll Meter, Minolta, Japan). The oil content (\%) of sunflower seeds was determined with the help of a nuclear magnetic resonance (NMR) analyzer (Newport Analyzer MK III A, Newport Instruments Ltd., Milton Keynes, England). The standardization of NMR was performed with $4 \mathrm{~g}$ seeds of known oil content. The seed samples were cleaned and dried for $3 \mathrm{~h}$ at $11^{\circ} \mathrm{C}$ in an oven and a representative sample of $2 \mathrm{~g}$ was then employed for oil content estimation. The oil content in each seed was calculated using the formula: CONSTANT $=$ NMR reading of calibration standard $/$ (weight of seed) $\times$ (oil content of the standard, by extraction $)$ and $\%$ OIL $=$ NMR reading of seed/(weight of dry sample) $\times$ (constant). The fatty acid composition (palmitic acid, stearic acid, oleic acid, linoleic acid) of sunflower oil was further determined using near-infrared (NIR) spectroscopy. The sunflower seeds were husked manually and their NIR spectra were scanned between 1100 to $2500 \mathrm{~nm}$ according to methods proposed by Sato et al. [58]. In order to assess the amount of root colonisation (percentage), the Phillips and Hayman staining technique [59] was used first, followed by the 'Giovannetti and Mosse' [60] method, both of which were carried out using a Lab Digital Trinocular Compound LED Microscope (Omax 40X-2500X, Kent, WA, USA). In order to calculate the proportion of AMF infected root segments, the following formula was used: 100/(number of root segments colonised/total number of root segments).

\subsection{Data Analysis}

Statgraphics Centurion XVI software was used for data analysis testing (StatPoint Technologies, Warrenton, VA, USA). A Newman-Keuls multiple-range test was used to statistically examine the findings, which were represented as mean values \pm standard deviation. The variance analysis and the Newman-Keuls multiple-range test were used to compute and statistically analyse the data acquired. In all cases, unless otherwise indicated, statistical significance was denoted by the value of $p<0.05$.

\section{Conclusions}

Drought is a widespread adverse limiting factor that affects plant growth, physiology, and metabolism in different ways. Drought stress has an impact on the morphological, physiological, biochemical, and metabolic pathways of plants, resulting in a decrease in plant productivity. AMF and PGPR are vital in enhancing plant response to biotic and abiotic challenges, as well as reducing the consequences of these stresses on plants. Their role in enhancing plant growth and output, disease resistance, biotic and abiotic tolerance, and reducing the use of harmful pesticides and industrial fertilizers is an environmentally acceptable approach for reducing the use of pesticides and industrial fertilizers. Inoculation with mycorrhizal fungi and growth-promoting rhizobacteria can be considered efficient in augmenting growth parameters and total crop yield. Arbuscular mycorrhizal fungi 
promote plant growth and crop yield by supplying the nutrients essential for the plants by developing an extra-radical hyphae network that increases the soil volume used by plant roots. Further, AMF root colonization helps in the absorption of nutrients and water from the soil, biocontrol of pathogens, production of plant hormones, and settlement of plantlets in unfavorable conditions.

Our experiment on sunflowers demonstrated distinct improvements in the quality and quantity attributes of almost all the plant parts including leaves, flowers, and seeds. All the morphological and biochemical parameters produced favorable results under integrated AMF and PGPR treatment, reflecting their efficiency to be used as biofertilizers. Further, it may be observed that bio-inoculation could be of much significance in water-stressed soils. The exogenic application of G. mosseae alone or with P. fluorescens alleviates the adverse effects of water stress on the sunflower yield and physiology. Moreover, inoculation of the studied micro-organisms G. mosseae and P. fluorescens are economically viable as well as sustainable, thus, they can be applied in fields for better growth and yield. Thus, we conclude that AMF and PGPR can possibly increase sunflower productivity while mitigating environmental degradation simultaneously.

Author Contributions: Conceptualization, P.K. and A.K.D.; Methodology, P.K. and M.S.; software analysis, P.K.; data curation, M.S.; writing, P.K. and M.S.; review and editing, A.K.D. and P.K.; supervision, A.K.D. and P.K. All authors have read and agreed to the published version of the manuscript.

Funding: This research received no external funding.

Institutional Review Board Statement: Not applicable.

Informed Consent Statement: Not applicable.

Data Availability Statement: Data is available on request.

Acknowledgments: Authors wish to thank the anonymous reviewers for their careful reading and corrections.

Conflicts of Interest: The authors declare no conflict of interest.

\section{References}

1. Oshundiya, F.O.; Olowe, V.I.O.; Sowemimo, F.A.; Odedina, J.N. Seed Yield and Quality of Sunflower (Helianthus annuus L.) as Influenced by Staggered Sowing and Organic Fertilizer Application in the Humid Tropics. Helia 2014, 37, 237-255. [CrossRef]

2. Guo, S.; Ge, Y.; Jom, K.N. A Review of Phytochemistry, Metabolite Changes, and Medicinal Uses of the Common Sunflower Seed and Sprouts (Helianthus annuus L.). Chem. Cent. J. 2017, 11, 95. [CrossRef] [PubMed]

3. Nafady, N.A.; Hashem, M.; Hassan, E.A.; Ahmed, H.A.; Alamri, S.A. The Combined Effect of Arbuscular Mycorrhizae and Plant-Growth-Promoting Yeast Improves Sunflower Defense against Macrophomina phaseolina Diseases. Biol. Control 2019, 138, 104049. [CrossRef]

4. Bhardwaj, D.; Ansari, M.W.; Sahoo, R.K.; Tuteja, N. Biofertilizers Function as Key Player in Sustainable Agriculture by Improving Soil Fertility, Plant Tolerance and Crop Productivity. Microb. Cell Factories 2014, 13, 66. [CrossRef]

5. Mwashasha, R.M.; Hunja, M.; Tani, A. Screening of Bacterial and Fungal Isolates for Their Plant Growth Promoting Activities. In Proceedings of the 2012 JKUAT Scientific, Technological and Industrialization Conference, Nairobi, Kenya, 15-16 November 2012.

6. Cecilia Fernández, M.; Hernán Gutiérrez Boem, F.; Rubio, G. Effect of Indigenous Mycorrhizal Colonization on PhosphorusAcquisition Efficiency in Soybean and Sunflower. J. Plant Nutr. Soil Sci. 2011, 174, 673-677. [CrossRef]

7. Saharan, B.S.; Nehra, V. Plant Growth Promoting Rhizobacteria: A Critical Review. Life Sci. Med. Res. 2011, 21, 30.

8. Diagne, N.; Ngom, M.; Djighaly, P.I.; Fall, D.; Hocher, V.; Svistoonoff, S. Roles of Arbuscular Mycorrhizal Fungi on Plant Growth and Performance: Importance in Biotic and Abiotic Stressed Regulation. Diversity 2020, 12, 370. [CrossRef]

9. Fahramand, M.; Adibian, M.; Sobhkhizi, A.; Noori, M.; Moradi, H.; Rigi, K. Effect of Arbuscular Mycorrhiza Fungi in Agronomy. J. Nov. Appl. Sci 2014, 3, 400-404.

10. Da Silva Campos, M.A. Bioprotection by Arbuscular Mycorrhizal Fungi in Plants Infected with Meloidogyne Nematodes: A Sustainable Alternative. Crop Prot. 2020, 135, 105203. [CrossRef]

11. Dowarah, B.; Gill, S.S.; Agarwala, N. Arbuscular Mycorrhizal Fungi in Conferring Tolerance to Biotic Stresses in Plants. J. Plant Growth Regul. 2021, 1-16. [CrossRef] 
12. Emmanuel, O.C.; Babalola, O.O. Productivity and Quality of Horticultural Crops through Co-Inoculation of Arbuscular Mycorrhizal Fungi and Plant Growth Promoting Bacteria. Microbiol. Res. 2020, 239, 126569. [CrossRef] [PubMed]

13. Jacott, C.N.; Murray, J.D.; Ridout, C.J. Trade-Offs in Arbuscular Mycorrhizal Symbiosis: Disease Resistance, Growth Responses and Perspectives for Crop Breeding. Agronomy 2017, 7, 75. [CrossRef]

14. Berdeni, D.; Cotton, T.E.A.; Daniell, T.J.; Bidartondo, M.I.; Cameron, D.D.; Evans, K.L. The Effects of Arbuscular Mycorrhizal Fungal Colonisation on Nutrient Status, Growth, Productivity, and Canker Resistance of Apple (Malus pumila). Front. Microbiol. 2018, 9, 1461. [CrossRef]

15. Juntahum, S.; Jongrungklang, N.; Kaewpradit, W.; Lumyong, S.; Boonlue, S. Impact of Arbuscular Mycorrhizal Fungi on Growth and Productivity of Sugarcane under Field Conditions. Sugar Tech 2020, 22, 451-459. [CrossRef]

16. Khoshru, B.; Mitra, D.; Khoshmanzar, E.; Myo, E.M.; Uniyal, N.; Mahakur, B.; Mohapatra, P.K.D.; Panneerselvam, P.; Boutaj, H.; Alizadeh, M. Current Scenario and Future Prospects of Plant Growth-Promoting Rhizobacteria: An Economic Valuable Resource for the Agriculture Revival under Stressful Conditions. J. Plant Nutr. 2020, 43, 3062-3092. [CrossRef]

17. Selvakumar, G.; Panneerselvam, P.; Ganeshamurthy, A.N. Bacterial Mediated Alleviation of Abiotic Stress in Crops. In Bacteria in Agrobiology: Stress Management; Springer: Berlin/Heidelberg, Germany, 2012; pp. 205-224.

18. David, B.V.; Chandrasehar, G.; Selvam, P.N. Pseudomonas fluorescens: A Plant-Growth-Promoting Rhizobacterium (PGPR) with Potential Role in Biocontrol of Pests of Crops. In Crop Improvement through Microbial Biotechnology; Elsevier: Amsterdam, The Netherlands, 2018; pp. 221-243.

19. Meena, M.; Swapnil, P.; Divyanshu, K.; Kumar, S.; Tripathi, Y.N.; Zehra, A.; Marwal, A.; Upadhyay, R.S. PGPR-Mediated Induction of Systemic Resistance and Physiochemical Alterations in Plants against the Pathogens: Current Perspectives. J. Basic Microbiol. 2020, 60, 828-861. [CrossRef]

20. Ahemad, M.; Kibret, M. Mechanisms and Applications of Plant Growth Promoting Rhizobacteria: Current Perspective. J. King Saud Univ. Sci. 2014, 26, 1-20. [CrossRef]

21. Gopalakrishnan, S.; Sathya, A.; Vijayabharathi, R.; Varshney, R.K.; Gowda, C.L.; Krishnamurthy, L. Plant Growth Promoting Rhizobia: Challenges and Opportunities. 3 Biotech 2015, 5, 355-377. [CrossRef] [PubMed]

22. Aini, N.; Yamika, W.S.D.; Ulum, B. Effect of Nutrient Concentration, PGPR and AMF on Plant Growth, Yield, and Nutrient Uptake of Hydroponic Lettuce. Int. J. Agric. Biol. 2019, 21, 175-183.

23. Mishra, V.; Gupta, A.; Kaur, P.; Singh, S.; Singh, N.; Gehlot, P.; Singh, J. Synergistic Effects of Arbuscular Mycorrhizal Fungi and Plant Growth Promoting Rhizobacteria in Bioremediation of Iron Contaminated Soils. Int. J. Phytoremediat. 2016, 18, 697-703. [CrossRef]

24. Behera, B.C.; Singdevsachan, S.K.; Mishra, R.R.; Dutta, S.K.; Thatoi, H.N. Diversity, Mechanism and Biotechnology of Phosphate Solubilising Microorganism in Mangrove-A Review. Biocatal. Agric. Biotechnol. 2014, 3, 97-110. [CrossRef]

25. Siddique, R.; Gul, A.; Ozturk, M.; Altay, V. Phosphate Solubilizing Bacteria for Soil Sustainability. In Handbook of Assisted and Amendment: Enhanced Sustainable Remediation Technology; John Wiley \& Sons: Hoboken, NJ, USA, 2021; pp. $423-435$.

26. Yadav, A.; Saini, I.; Kaushik, P.; Ansari, M.A.; Khan, M.R.; Haq, N. Effects of Arbuscular Mycorrhizal Fungi and P-Solubilizing Pseudomonas fluorescence (ATCC-17400) on Morphological Traits and Mineral Content of Sesame. Saudi J. Biol. Sci. 2021, 28, 2649-2654. [CrossRef] [PubMed]

27. Mazumdar, D.; Saha, S.P.; Ghosh, S. RSM Based Optimization of Plant Growth Promoting Rhizobacteria and Nitrogen Dosage for Enhanced Growth and Yield of Mustard (Brassica campestris L.). J. Plant Nutr. 2021, 44, 2228-2244. [CrossRef]

28. Sarwat, M.; Hashem, A.; Ahanger, M.A.; Abd_Allah, E.F.; Alqarawi, A.A.; Alyemeni, M.N.; Ahmad, P.; Gucel, S. Mitigation of $\mathrm{NaCl}$ Stress by Arbuscular Mycorrhizal Fungi through the Modulation of Osmolytes, Antioxidants and Secondary Metabolites in Mustard (Brassica juncea L.) Plants. Front. Plant Sci. 2016, 7, 869. [CrossRef]

29. Yasmeen, T.; Tariq, M.; Iqbal, S.; Arif, M.S.; Riaz, M.; Shahzad, S.M.; Ali, S.; Noman, M.; Li, T. Ameliorative Capability of Plant Growth Promoting Rhizobacteria (PGPR) and Arbuscular Mycorrhizal Fungi (AMF) against Salt Stress in Plant. In Plant Abiotic Stress Tolerance; Springer: Cham, Switzerland, 2019; pp. 409-448.

30. Al-Amri, S.M. Application of Bio-Fertilizers for Enhancing Growth and Yield of Common Bean Plants Grown under Water Stress Conditions. Saudi J. Biol. Sci. 2021, 28, 3901-3908. [CrossRef]

31. Delavaux, C.S.; Smith-Ramesh, L.M.; Kuebbing, S.E. Beyond Nutrients: A Meta-Analysis of the Diverse Effects of Arbuscular Mycorrhizal Fungi on Plants and Soils. Ecology 2017, 98, 2111-2119. [CrossRef]

32. Akbari, P.; Ghalavand, A.; Sanavy, A.M.; AghaAlikhani, M.; Kalkhoran, S. Comparison of Different Nutritional Levels and the Effect of Plant Growth Promoting Rhizobacteria (PGPR) on the Grain Yield and Quality of Sunflower. Aust. J. Crop Sci. 2011, 5, 1570-1576.

33. Ibrahim, M. Sunflower Response to Inoculation with Single and Mixed Species of Arbuscular Mycorrhizal Fungi: Agronomic Characteristics. Acta Agric. Slov. 2019, 113, 321-327. [CrossRef]

34. Arif, M.S.; Riaz, M.; Shahzad, S.M.; Yasmeen, T.; Akhtar, M.J.; Riaz, M.A.; Jassey, V.E.; Bragazza, L.; Buttler, A. Associative Interplay of Plant Growth Promoting Rhizobacteria (Pseudomonas aeruginosa QS40) with Nitrogen Fertilizers Improves Sunflower (Helianthus annuus L.) Productivity and Fertility of Aridisol. Appl. Soil Ecol. 2016, 108, 238-247. [CrossRef]

35. Bilalis, D.J.; Karamanos, A.J. Organic Maize Growth and Mycorrhizal Root Colonization Response to Tillage and Organic Fertilization. J. Sustain. Agric. 2010, 34, 836-849. [CrossRef] 
36. Gholamhoseini, M.; Ghalavand, A.; Dolatabadian, A.; Jamshidi, E.; Khodaei-Joghan, A. Effects of Arbuscular Mycorrhizal Inoculation on Growth, Yield, Nutrient Uptake and Irrigation Water Productivity of Sunflowers Grown under Drought Stress. Agric. Water Manag. 2013, 117, 106-114. [CrossRef]

37. Begum, N.; Qin, C.; Ahanger, M.A.; Raza, S.; Khan, M.I.; Ashraf, M.; Ahmed, N.; Zhang, L. Role of Arbuscular Mycorrhizal Fungi in Plant Growth Regulation: Implications in Abiotic Stress Tolerance. Front. Plant Sci. 2019, 10, 1068. [CrossRef]

38. Yadav, A.; Yadav, K.; Aggarwal, A. Impact of Arbuscular Mycorrhizal Fungi with Trichoderma Viride and Pseudomonas fluorescens on Growth, Yield and Oil Content in Helianthus annuus L. J. Essent. Oil Bear. Plants 2015, 18, 444-454. [CrossRef]

39. Krudnak, A.; Wonprasaid, S.; Machikowa, T. Boron Affects Pollen Viability and Seed Set in Sunflowers. Afr. J. Agric. Res. 2013, 8, 162-166.

40. Gormus, O.; Barutcular, C. Boron Nutrition Studies with Cotton and Sunflower in Southern Turkey. Commun. Soil Sci. Plant Anal. 2016, 47, 915-929. [CrossRef]

41. Khalid, D.; Saad, D.; Kacem, M.; Ezzahra, N.F.; Fouad, A.; Abdelhadi, A.H. Sunflower Response to Boron Supply When Grown in a Silty Clay Soil. J. Saudi Soc. Agric. Sci. 2020, 19, 81-86. [CrossRef]

42. Emery, S.M.; Kinnetz, E.R.; Bell-Dereske, L.; Stahlheber, K.A.; Gross, K.L.; Pennington, D. Low Variation in Arbuscular Mycorrhizal Fungal Associations and Effects on Biomass among Switchgrass Cultivars. Biomass Bioenergy 2018, 119, 503-508. [CrossRef]

43. Begum, N.; Ahanger, M.A.; Su, Y.; Lei, Y.; Mustafa, N.S.A.; Ahmad, P.; Zhang, L. Improved Drought Tolerance by AMF Inoculation in Maize (Zea mays) Involves Physiological and Biochemical Implications. Plants 2019, 8, 579. [CrossRef] [PubMed]

44. Mathur, S.; Sharma, M.P.; Jajoo, A. Improved Photosynthetic Efficacy of Maize (Zea mays) Plants with Arbuscular Mycorrhizal Fungi (AMF) under High Temperature Stress. J. Photochem. Photobiol. B Biol. 2018, 180, 149-154. [CrossRef]

45. Sharma, D.; Gahtyari, N.C.; Chhabra, R.; Kumar, D. Role of Microbes in Improving Plant Growth and Soil Health for Sustainable Agriculture. In Advances in Plant Microbiome and Sustainable Agriculture; Springer: Singapore, 2020; pp. 207-256.

46. Chandrasekaran, M.; Chanratana, M.; Kim, K.; Seshadri, S.; Sa, T. Impact of Arbuscular Mycorrhizal Fungi on Photosynthesis, Water Status, and Gas Exchange of Plants under Salt Stress-A Meta-Analysis. Front. Plant Sci. 2019, 10, 457. [CrossRef]

47. Bona, E.; Lingua, G.; Manassero, P.; Cantamessa, S.; Marsano, F.; Todeschini, V.; Copetta, A.; D’Agostino, G.; Massa, N.; Avidano, L. AM Fungi and PGP Pseudomonads Increase Flowering, Fruit Production, and Vitamin Content in Strawberry Grown at Low Nitrogen and Phosphorus Levels. Mycorrhiza 2015, 25, 181-193. [CrossRef]

48. Ludwig-Müller, J. Hormonal Responses in Host Plants Triggered by Arbuscular Mycorrhizal Fungi. In Arbuscular Mycorrhizas: Physiology and Function; Springer: Dordrecht, The Netherlands, 2010; pp. 169-190.

49. Etesami, H.; Maheshwari, D.K. Use of Plant Growth Promoting Rhizobacteria (PGPRs) with Multiple Plant Growth Promoting Traits in Stress Agriculture: Action Mechanisms and Future Prospects. Ecotoxicol. Environ. Saf. 2018, 156, 225-246. [CrossRef]

50. Ojuederie, O.B.; Olanrewaju, O.S.; Babalola, O.O. Plant Growth Promoting Rhizobacterial Mitigation of Drought Stress in Crop Plants: Implications for Sustainable Agriculture. Agronomy 2019, 9, 712. [CrossRef]

51. Plouznikoff, K.; Declerck, S.; Calonne-Salmon, M. Mitigating Abiotic Stresses in Crop Plants by Arbuscular Mycorrhizal Fungi. In Belowground Defence Strategies in Plants; Springer: Cham, Switzerland, 2016; pp. 341-400.

52. Garg, N.; Bhandari, P. Interactive Effects of Silicon and Arbuscular Mycorrhiza in Modulating Ascorbate-Glutathione Cycle and Antioxidant Scavenging Capacity in Differentially Salt-Tolerant Cicer arietinum L. Genotypes Subjected to Long-Term Salinity. Protoplasma 2016, 253, 1325-1345. [CrossRef]

53. Meena, R.K.; Reddy, K.S.; Gautam, R.; Maddela, S.; Reddy, A.R.; Gudipalli, P. Improved Photosynthetic Characteristics Correlated with Enhanced Biomass in a Heterotic F 1 Hybrid of Maize (Zea mays L.). Photosynth. Res. 2021, 147, 253-267. [CrossRef] [PubMed]

54. Majeed, A.; Abbasi, M.K.; Hameed, S.; Yasmin, S.; Hanif, M.K.; Naqqash, T.; Imran, A. Pseudomonas Sp. AF-54 Containing Multiple Plant Beneficial Traits Acts as Growth Enhancer of Helianthus annuus L. under Reduced Fertilizer Input. Microbiol. Res. 2018, 216, 56-69. [CrossRef]

55. Tyagi, V.; Dhillon, S.K.; Kaushik, P.; Kaur, G. Characterization for Drought Tolerance and Physiological Efficiency in Novel Cytoplasmic Male Sterile Sources of Sunflower (Helianthus annuus L.). Agronomy 2018, 8, 232. [CrossRef]

56. Hoagland, D.R.; Arnon, D.I. The Water-Culture Method for Growing Plants without Soil; Circular; California Agricultural Experiment Station: Berkley, CA, USA, 1950; Volume 347.

57. Tyagi, V.; Dhillon, S.K.; Kaur, G.; Kaushik, P. Heterotic Effect of Different Cytoplasmic Combinations in Sunflower Hybrids Cultivated Under Diverse Irrigation Regimes. Plants 2020, 9, 465. [CrossRef]

58. Sato, T.; Takahata, Y.; Noda, T.; Yanagisawa, T.; Morishita, T.; Sakai, S. Nondestructive Determination of Fatty Acid Composition of Husked Sunflower ( Helianthus annua L.) Seeds by near-Infrared Spectroscopy. J. Am. Oil Chem. Soc. 1995, 72, 1177-1183. [CrossRef]

59. Phillips, J.M.; Hayman, D.S. Improved Procedures for Clearing Roots and Staining Parasitic and Vesicular-Arbuscular Mycorrhizal Fungi for Rapid Assessment of Infection. Trans. Br. Mycol. Soc. 1970, 55, 158-161. [CrossRef]

60. Giovannetti, M.; Mosse, B. An Evaluation of Techniques for Measuring Vesicular Arbuscular Mycorrhizal Infection in Roots. New Phytol. 1980, 84, 489-500. [CrossRef] 